\title{
CAUSALITY RELATIONSHIP BETWEEN EXPORT EXPANSION AND ECONOMIC GROWTH: Empirical Evidence for Turkey
}

\author{
Erol CAKMAK* \\ M. Sinan TEMURLENK*
}

\begin{abstract}
This paper investigates the causality relationship between export expansion and economic growth in Turkey, using data for the period from 1968 to 1993. A great number of emprical studies have shown that export expansion is associated with better economic performance in many developing countries. This is used to support the export-oriented development strategies. Such a broad interpretation is, however, usually based on regression analyses which provide no means of determining the direction of causality. A brief literature survey on the relationship between export growth and economic growth is carried out and some leading studies on causality testing are examined. Hsiao version of Granger causality test technique is employed in an emprical study for Turkey. Although the results seem to give no support to the export-led growth hypothesis for Turkey in the framework of causality testing, more caution is needed to interpret them in a conclusive way, mainly because of shorter experience of export promotion policies in Turkey compared with the many other developing countries.
\end{abstract}

\section{Introduction}

There has been continuing discussion in the literature about the relationship between export expansion and economic growth for the recent three decades. At the theoretical level, there are two diverse positions: The standard neoclassical trade argument postulates that export expansion creates a substantial positive impact on economic performance due to better allocation of resources. A policy based on expont expansion is assumed to allow higher capacity utilization and exploitation of scale economies, thus causes higher growth rates of output and employment, and provides more opportunity in accruing technological innovations. ${ }^{(1)}$ On the other hand, for Marxist or neo-Marxist

\footnotetext{
- Alaturk University. Faculty of Economics and Administrative Sciences, Erzurum. The authors would like to thank Ercan Uygur of Ankara University for his comments. The responsibility for any errors remaining is ours only.
} 
stances, trade is a kind of mechanism with which industrialized countries exploit the developing ones. (2)

In spite of the diversity in theoretical positions, emprical studies emerged a consensus among many development economists that export expansion causes a better economic performance in developing countries. These studies investigated the relation on either individual countries with time-series data or some group of developing countries crosis-sectionally. Each study gave its main importance to the different aspects of the relationship, such as its relevance to level of economic development, trade orientation or commodity composition of exports, etc. ${ }^{(3)}$ Though they differed from each other in terms of the period analysed and the set of developing countries included, their results generally gave support to the hypothesis that export expansion plays an important role in economic growth in developing countries. A common feature of the emprical studies has been to investigate the relationship between export growth and economic growth on $a$ priori grounds that the former causes the latter.

From the methodological point of view, these studies may be summarized in three groups: The first includes the studies employing simple regression models. Emery (1967), Syron and Walsh (1968), Maizels (1968), Massell (1972), Michaely (1977), Donges and Riedel (1977) all used simple regression methodology in determining the role of export growth in economic growth.

The emprical studies in the second group investigated the relationship through the induced forms of dual-gap and/or Harrod-Domar models. The leading studies were done by Voivodas (1973 and 1974), Williamson (1978) and Fajana (1979).

Finally, the third and more commonly used approach is based on some models derived from Cobb-Douglas production function. Studies by Michaloupoulos and Jay (1973), Balassa (1978, 1985), Tyler (1981), Feder (1982), Salvatore (1983), Kavoussi (1984), Ram (1985 and 1987), Otani and Villanueva (1990) and Sheehey $(1990,1992)$ may be quoted here.

\section{The Causality Problem}

Although almost all of the above studies generally found a strong relationship between export growth and economic growth and are highly illuminative for further studies in respect to the relevance of the relationship to the trade orientation and the level of economic development as well as the commodity composition of exports, they, regardless of the methodology employed, have interpreted their results in regression of output variables on exports for providing support to export-promotion development strakegy. In fact, a unidirectional causality from export expansion to the development of economic growth were used as credit to the export-led growth strategy. Such an interpretation should be questionable since those regressions provide no means of determining the direction of causality. In regression models, export expansion is considered as regressor while economic growth is taken as regressand. Accordingly, a statistically significant coefficient of export expansion variable is interpreted in such a way that export growth causes economic growth. Such an approach suffers from an important methodological weakness, as one easily suggests that economic growth may well cause export expansion, instead of vice versa. She can even rationalize her suggestion as follows: Together with economic growth process, improvements would be 
gained in technology, human and physical capital, technology transfer and production techniques, all of which determine the causality from economic growth to export growth. In fach, rapid economic growth, as suggested by Goldstein and Khan (1982), may increase a country's export capacity. For example, economic growth increases various infrastructure facilities such as roads, transportation, and communications, which support export industries. On the other hand, economic growth may also lead to a reduction in export growth if exportable goods are competitive in the domestic market. Increasing income may raise domestic consuption, leaving fewer goods available for exports. All these considerations raised the question of causality direction in the relationship between export growth and economic growth and caused emprical efforts to be shifted from the sole regression-based models to the causality seeking studies.

Being aware of the question, Jung and Marshall $(1985)^{(4)}$ performed causality tests for thirty-seven developing countries by using an approach developed by Granger (1969). They used different time periods for each country determined by the availability of annual data changing from 1950 to 1980 . Through Granger approach, the output growth rate is regressed on a constant, on past values of itself, and on past values of the export growth rate. The same treatment is also performed on export growth. This study limited the length of the lag to two for each right-hand side variable of the equations. Jung and Marshall concluded that the causality was detected only in fourteen countries. Export growth caused economic growth in seven countries, and economic growth created export growth in seven countries. They suggested that "this unexpected result was due to data processing differences as their study was based on time series, but all previous research used the data processed cross-sectionally".(5) Turkey was included in this study with data comprising years from 1953 to 1978 and no causality was detected. A weak point in this study is that their use of the Granger test of causality suffered from arbitrariness in the choice of lags and the level of significance. To overcome this, Hsiao (1981) suggested using a combination of Granger causality test with Akaike's Final Prediction Error (FPE) criterion. He showed that the causality direction was from exports to economic growth for only four countries.

Another earlier test of causality was done by Chow (1987), based on an approach developed by Sims (1972). Chow used annual data on exports and manufacturing production from eight newly industrializing countries (NICs), for the decades of 1960 s and 1970s. He found a strong causal relationship between expor growth and industrial development. A majority of these countries exhibited bidirectional causalities between the growth of exports and the development of manufacturing industries. His results may be considered as supporting export expansion hypothesis.

Bahmani-Oskooee, et al. (1991) utilized Hsiao's Granger-Akaike synthesis for testing the causality in 20 developing countries, all of which were included in Jung and Marshall's sample, from 1960 to 1985 . They found that causality ran from export growth to economic growth in ten countries and the reverse causality occured in seven countries. They concluded that their results was not conclusive enough in evaluating competing hypothesis.

Recently, Dodaro (1993) investigated the relationship between export expansion and economic growth in a sample of 57 developing countries from different levels of economic development. His results were rather mixed and offered very weak support for 
the contention that export growth promotes GDP growth. The results of these four research are presented in Table 1.

As an example for panel data studies, Ahmad and Kwan (1991) examine the relationship in the African continent for $\mathbf{4 7}$ countries by using the data for the period 1981-1987. Their causality inferences indicate no causal link from exports to economic growth, or vice versa. They concluded that "current causality tests on the relationship between exports and economic growth suffer from incomplete specification due to exclusion of variables that are crucial but are omitted".(6)

Several other studies were carried out either on an individual country framework, for example, for Taiwan, Japan and USA by Ghartey (1993), for Ghana by Gordon and Sakyi-Bekoe (1993), for Portugal by Oxley (1993), for South Korea by Suliman, et al. (1993) and Sengupta and Espana (1994) or on a country group framework as done by Bahrmani-Oskooee and Alse (1993). These studies exerted mixed results in testing the relevant hypothesis. 


\section{Table 1. The Direction of Causality Between Export Growth and Economic Growth in Developing Countries}

\begin{tabular}{|c|c|c|c|}
\hline Sudy by & $\begin{array}{l}\text { Expon Growth } \\
\text { Causes } \\
\text { Economic Growth }\end{array}$ & $\begin{array}{l}\text { Economic Growth } \\
\text { Causes } \\
\text { Expon Growth }\end{array}$ & No Causality \\
\hline $\begin{array}{l}\text { Jung and } \\
\text { Marshall } \\
(1985) \\
(1950-1980)\end{array}$ & 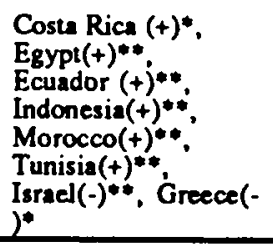 & 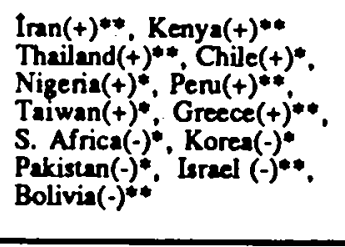 & $\begin{array}{l}\text { Turkey, Venezuela, India, } \\
\text { Philippines, Mexico, Sri } \\
\text { Lanka, Portuga, Guyana, } \\
\text { Jamaica, Parguay, Uruguny, } \\
\text { Brazil, Argentina, Columbia, } \\
\text { Guatemala, E Sahvador, } \\
\text { Honduras }\end{array}$ \\
\hline $\begin{array}{l}\text { Chow (1987) } \\
(1960-1984)\end{array}$ & $\begin{array}{l}\text { Brazil }(+)^{* * *} \\
\text { Korea }(+)^{* * *}, \\
\text { Israel }(+)^{* * *} \\
\text { Hon Kong }(t) * * * \\
\text { Mexico }(+)^{* * *} \\
\text { Singapore }(+)^{* * *} \text {, } \\
\text { Taiwan }(+)^{* * *}\end{array}$ & $\begin{array}{l}\text { Brazil }(+)^{* *} \text { Korea }(t)^{* * *} \text {. } \\
\text { Hong Kong(t)**, } \\
\text { Israel }(+)^{* * *} \\
\text { Singapore }(+)^{* * *} \\
\text { Taiwan }(+)^{* * *}\end{array}$ & Argentina \\
\hline $\begin{array}{l}\text { Bahmani- } \\
\text { Oskooee. } \\
\text { et al. }(1991) \\
(1951-1987)\end{array}$ & $\begin{array}{l}\text { Dominican } \\
\text { Rebuplic }(+)^{* *} \\
\text { Thailand }(t)^{*} \text {, } \\
\text { Taiwan }(+)^{*} \\
\text { Indonesia }(t)^{*} \text {, } \\
\text { Korea }(t)^{*} \\
\text { Paraguay }(-)^{* *} \\
\text { El Salvador }(-)^{*}\end{array}$ & $\begin{array}{l}\text { S. Africa }(+)^{* *} \text {, Korea }(+)^{* *} \\
\text { Nigeria }(+)^{* *} \\
\text { Indonesia }(-)^{* *}\end{array}$ & $\begin{array}{l}\text { Brazil, Ecuador, Greece, Sri } \\
\text { Lanka, Honduras, Jamaica, } \\
\text { Morocos, Tunisia, } \\
\text { Philippines, Guyena }\end{array}$ \\
\hline
\end{tabular}

\begin{tabular}{|c|c|c|}
\hline $\begin{array}{l}\text { Dodaro } \\
(1993) \\
(1967.1986)\end{array}$ & $\begin{array}{l}\text { Bangladesh }(+)^{* *} \text {, } \\
\text { Uganda }(+)^{*} \\
\text { Indonesia }(+)^{* * *} \text {, } \\
\text { Malta }(+)^{*} \text { Costa } \\
\text { Rica }(+)^{*} \text { Israel }(+)^{*} \text {, } \\
\text { P. New Guinea }(+)^{*} \text {, } \\
\text { Syria }(-)^{*} \text {. } \\
\text { Ethiopya(-)**, } \\
\text { Malaysia }(-)^{*} \text {. } \\
\text { El Salvador }(-)^{* *}\end{array}$ & 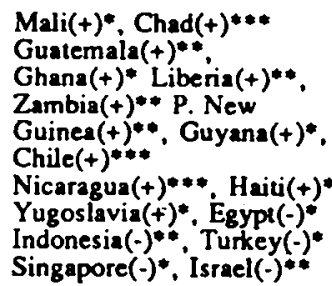 \\
\hline
\end{tabular}

Nepal, Somslia, India, Fiji, Bunundi, Burkina Faso, Malavi, Ruanda, Benin, Sri Lenka, S. Leone, Togo, Zaire, Niger, Morocco, Pakistan, Tanzania, Cyprus. Gambia, C. African Rep., Madagascar, Suriname. Mauritania, Lesotho, Jordan, Sudan, Kenya, Senegul, Cameroon, Hondurs, Zimbsbwe, Thailand, Bolivin, Philippines, Yemen, Congo, Nigena, Bostwana, Sweziland, Peru, Mauritius. Tunisia, Columbie, Ivory Coast, Paraguay. Ecuador. Dom. Rep., Barbados, Korea, Algeria, Jamica, Mexico, Brazil, Uruguay, Panama, S. Africa, Greece, Mauritenia. Lesotho, Trinidad and Tobago, 


\section{Testing for Causality: Emprical Study for Turkey, 1968-1993}

The purpose of our emprical study is to test the causal relationship between economic growth and export growth in Turkey for the period 1968-1993. Turkey undertook a major liberalization of trade policies in 1980s, after a long history of import subsitution and exchange controls. As noted before, Jung and Marshall found no causality for Turkey in their studies. They, however, used the data comprising years between 1958 and 1973. On the other hand, Dodaro found a causal relation from GDP growth to export growth at 10 percent significance level with data for the period 1967-1986, as seen from Table 1.

The first study excludes the years of trade liberalization during which exports increased to a great extent, or as many claimed, an export boom has been experienced. The second study covered only the half of 1980s. While Jung and Marshall found no causality in any direction, Dodaro detected a causal link in reverse of the export-led growth hypothesis with a negative sign implying that GDP growth reduces export growth in Turkey. We think that it is worthy to try another test with a longer period of time (1968-1993) covering the whole experience of trade liberalization until 1993. On the other hand, the Granger test used by Jung and Marshall suffers from arbitrariness in the choice of lags while Dodaro's study uses F statistics in choosing the lag lengths. To overcome this shortcoming we employ Hsioa version of Granger causality based on Akaike's Final Prediction Error (FPE) criterion. We also perform unit roots and cointegration tests in order to determine the time series properties of the variables.

As commonly used in many other studies, we take gross domestic product (GDP) as an indicator of economic performance. Export variable (EXP) is defined as merchandise exports. Both series were deflated with implicit GNP deflator and transformed into their log levels. Data were taken from the series compiled by Turkish Institute of State Statistics. GDP series are the new ones computed on the basis of the 1987 input-output table. (7) As an extension to our analysis, we also investigate the relationship between the growth of manufactured production (MFP) and the growth of total merchandise exports. The rationale behind this extension is the fact that Turkey has experienced a remarkable increase in her manufactured exports after 1980's. Accordingly, a definite causal relationship from exports to manufactured production may be interpreted as credit to export-led growth strategy in Turkey.

\section{Integration and Cointegration}

The time properties of the variables must be examined in order to ensure confidence in causality. If the variables follow random walks, regressing one variable on another may result in spurious parameter estimators, being not consistent. These variables become stationary when differenced. However, conventional differencing approach disregards potentially important equilibrium relationships among the levels of series to which the hypotheses of economic theory usually apply, as suggested by Engle and Granger (1987). Accordingly, a non stationary variable set may be treated in levels, if it is cointegrated. Therefore, when the variables are both non stationary and are not cointegrate, differencing would be the only approach to follow. 
In determining whether the variables follow random walks we use a unit roots test proposed Dickey and Fuller (1979). This test is based on the estimation of the following equation in which both unrestricted and restricted $(\beta=0, \rho=1)$ forms.

$$
Y_{t}-Y_{t-1}=\alpha+\beta t-(\rho-1) Y_{t-1}+\gamma \Delta Y_{t-1}
$$

Whether the restrictions hold is tested by the standard $F$ ratio. ${ }^{(8)}$ The results of unit roots test are given in Table 2.

Table 2. Tests for Unit Roots of the Series

\begin{tabular}{lc}
\hline Variable & F \\
\hline $\log ($ GDP) & 3.44 \\
$\log ($ EXP) & 1.27 \\
$\log$ (MFP) & 2.53 \\
\hline
\end{tabular}

"Critical $\mathrm{F}$ value at $5 \%$ significance level is 7.24

Standart $\mathrm{F}$ ratios show that all variables follow random walks since the null hypothesis can not be rejected at $5 \%$ significance level. Although a unit root has been confirmed for the series, the question of cointegration still remains. In testing for cointegration, we took two steps. First, we estimate the regression equations for each underlying relations in their simple linear forms. Secondly, residuals(e) obtained from these regressions were subjected to Dickey-Fuller test again. The results are shown in Table 3.

Tablo 3. Tests for Cointegration between the Series

\begin{tabular}{lc}
\hline$a$ & $F^{*}$ \\
\hline $\log (G D P)=a+b \log (E X P)$ & 1.67 \\
$\log (E X P)=a+b \log ($ GDP) & 1.66 \\
$\log (M F D)=a+b \log$ (EXP) & 1.42 \\
$\log (E X P)=a+b \log$ (MFD) & 1.47 \\
\hline
\end{tabular}

*Critical $F$ value at 5 percent significance is 7.24 . 
As seen, none of the pair of variables are cointegrated according to the F statistics. As a conclusion, it is proved that the series follow random walks and are not cointegrated. Having characterized the trend properties of the data, we can now tum to caustlity testing by taking the first order differences of the variables.

\section{Procedure for Detecting Causality}

According to Granger mean causality, a time series $X_{t}$ is Granger-caused by a time series $Y_{t}$, if in a regression of $X_{t}$ on past values of $X$ and $Y$, the coefficicents of the $Y s$ are significantly different from zero. That is, the variable $X$ is better predicted when past information of $Y$ is taken into consideration, in addition to past values of $X$.

Granger causality running from $X$ to $Y$ is also defined in the same way as above. Therefore, when $X$ causes $Y(X \rightarrow Y)$ and $Y$ causes $X(Y \rightarrow X)$ in a bivariate system, we have a feedback $(X \leftrightarrow Y)$ relation between the variables. The concept of independence follows if neither $X$ causes $Y(X+Y)$ nor $Y$ causes $X(Y+X)$.

For our emprical purposes, we estimate the equation

$$
\Delta \log \mathrm{GDP}_{\mathrm{t}}=\mathrm{a}+\sum_{j=1}^{\mathrm{m}} \alpha_{\mathrm{j}} \Delta \log \mathrm{GDP}_{\mathrm{t}-\mathrm{j}}+\sum_{j=1}^{\mathrm{n}} \beta_{\mathrm{j}} \Delta \log \operatorname{EXP}_{\mathrm{t}-\mathrm{j}}+\mathrm{u}_{\mathrm{t}}
$$

for the hypothesis that export growth causes economic growth and

$$
\Delta \log \operatorname{EXP}_{t}=b+\sum_{j=1}^{k} \gamma_{j} \Delta \log \operatorname{EXP}_{t-j}+\sum_{j=1}^{l} \lambda_{j} \Delta \log \operatorname{GDP}_{t-j}+w_{t}
$$

for the hypothesis that economic growth causes export growth, where $u_{t}$ and $w_{t}$ are white noise error terms ${ }^{(9)}$, and $m, n, k$, and $l$ are assumed to be finite.

As suggested by Hsiao (1981) a two step procedure is followed in order to choose the optimum lag lengths. We explain the procedure employed by focusing only on eq. 2 as follows:

First, we estimate eq. (2) with the restriction that $\stackrel{n}{\Sigma}_{j} \beta_{j}$ using the FPE criterion, $j=1$

$$
\left(\frac{T+m+1}{T-m-1}\right) \sum_{t=1}^{T} \frac{\left(y_{t}-\hat{y}_{t}\right)^{2}}{T}
$$


where $T$ is the number of observations and $m$ is the order of lags varying from $110 \mathrm{~m}$. The specific value of $m$ that minimizes FPE will be the optimum number of lags when GDP is regressed against its own lags. criterion,

In the second step, we estimate eq. (2), now with no restriction, using the FPE

$$
\left(\frac{T+m+n+1}{T-m-n-1}\right) \sum_{t=1}^{T} \frac{\left(y_{t}-\hat{y}_{t}\right)^{2}}{T}
$$

where $\mathrm{n}$ is the order of lags on EXP.

Then we obtain resticted and unrestricted sums of squared residuals, as SSR $\mathbf{R}_{\mathbf{R}}$ and SSRU, respectively. By using them, we calculate, Lagrange Multiplier (LM), Likelihood Ratio (LR) and Wald (W) statistics which are altemative to each other as statistics testing the null hypothesis. $\sum_{j=1}^{n} \beta_{j}=0$ These statistics are calculated with the following formulas.

$$
\begin{gathered}
\mathrm{LM}=\frac{\mathrm{T}\left(\sigma_{\mathrm{R}}^{2}-\sigma_{U}^{2}\right)}{\sigma_{U}^{2}} \\
\mathrm{LR}=\mathrm{T} \log \frac{\sigma_{\mathrm{P}}^{2}}{2} \\
\sigma_{U} \\
\mathrm{~W}=\frac{\mathrm{T}\left(\sigma_{\mathrm{R}}^{2} \cdot \sigma_{U}^{2}\right.}{2} \\
\sigma_{U}^{2}
\end{gathered}
$$

where $\sigma^{2} R$ and $\sigma^{2} U$ are measured as ML estimator of the variance of disturbance terms and calculated as SSRR/T-n and SSRU/T-n-m, respectively. The whole procedure is repeated for eq. (3) in which $\Delta \log$ (EXP) is dependent variable.

A Box-Pierce Portmanteau Q-statistic is calculated for each regression to ensure that errors are white noise. The results are reported in Table 4. Box-Pierce $Q$ statistics show that the hypothesis of no residual autocorrelation can not be rejected. The signs indicate the effect of the independent variable on the dependent one. 
Table 4. The Results of Causality Tests

\begin{tabular}{|c|c|c|c|c|c|c|c|}
\hline $\begin{array}{l}\text { Direction of } \\
\text { Causality }\end{array}$ & Lag & Sign & LM & LR & W & d.f. & $\begin{array}{l}\text { Box- } \\
\text { Pierce } \\
Q(3) \\
\end{array}$ \\
\hline$\Delta \log (\mathrm{EXP}) \rightarrow \Delta \log (\mathrm{GDP})$ & $(3,1)$ & $H$ & 2.52 & 3.13 & 3.37 & 3 & 2.45 \\
\hline$\Delta \log (\mathrm{GDP}) \rightarrow \Delta \log (\mathrm{EXP})$ & $(3,1)$ & $(-)$ & $6.50^{*}$ & $7.92^{* *}$ & $9.53^{* *}$ & 3 & 1.69 \\
\hline$\Delta \log (\mathrm{EXP}) \rightarrow \Delta \log (\mathrm{MFP})$ & $(3,2)$ & $(\rightarrow)$ & 4.42 & 4.94 & 5.54 & 3 & 2.76 \\
\hline$\Delta \log (\mathrm{MFP}) \rightarrow \Delta \log (\mathrm{EXP})$ & $(3,1)$ & $(-)$ & $7.55^{*}$ & $9.25^{* *}$ & $11.50^{* * *}$ & 3 & 0.98 \\
\hline
\end{tabular}

*** and *** $\chi^{2}$ values at 10,5 , and 1 percent significance levels are $6,25,7.81$, and 11.34 for d.f. $=3$.

As for causality from economic growth to export growth, our study indicates negative causation in both $\log (\mathrm{GDP}) \rightarrow \log (\mathrm{EXP})$ and $\log (\mathrm{MFP}) \rightarrow \log (\mathrm{EXP})$ relations. The results are statistically significant at all chosen significance levels. This result may be intrerpreted in such a way that Turkey has not experienced an internally generated export growth process. Instead, economic growth has retarded export growth during the study period. This implies that the demand effects of output growth is sufficient to reduce the growth of exports. Jung and Marshall explained this rather contradictory result as follows:

"Real growth that is induced by an exogenous increase in consumer demand that is heavily concentrated in exportable and non-traded goods could lead to a decline in exports. Thus, output growth could cause decreased export growth"(10).

In fact, economic growth may lead to a reduction in export growth, especially if exportable goods are competitive in the domestic market. In such a case, increasing income may raise domestic consumption, thus leaving fewer goods available for exports.

On the other hand, the results exhibit that there is no causality from export growth to economic growth since the test statistics in this direction are statistically insignificant at all chosen significance levels. This may imply that the hypothesis of export-led growth is not verified for Turkey for the study period, in the context of Granger mean causality. Significant test statistics showing that export growth retards economic growth would be attributed to the import substitution strategies with the contention that such strategies distort the economy because of the underlying protective measures, then export could increase the extent of such distortions (particularly if the exports sector itself has benefited from prior protection), thus retarding or at best not contributing to economic growth(11). For such a process, one may suggest that exports are promoted at the expense of domestic consumption and efficiency. 


\section{Concluding Remarks}

In this study we investigate the relationship between export growth and economic growth in Turkey for the period from 1968 to 1993 by using the Hsiao version of Granger causality test. The results give no support to the export-led growth hypothesis in Turkey in the context of Granger mean causality. Though this is contrary to the conventional wisdom, similar results were also found by many development economists for many developing countries as noted in our literature survey. As far as Turkey is concemed Dodaro also found a negative causality from economic growth to export growth with the annual data covering the period from 1967 to 1986 (12) $^{(12)}$ Extending the study period to 1993 and adding a new causal relation concept between exports and manufactured production in this study does not change the results but strengthen them.

Whether exports are promoted at the expense of domestic consumption and effeciency or economic growth causes reduction in export growth due to decreasing availability of exportable goods is an issue to be addressed in further studies.

\section{NOTES}

1. For detailed theoretical explanations, see, for example, A. O Krueger, "Trade Policy as an Input to Development", American Economic Review, 1980, 70 (2), pp. 288-292., and J. Riedel, Myths and Reality of External Constraints on Development, Gower, 1987, London.

2. Sea A. G. Frank, Capitalism and Underdevelopment, in Latin America, Monthly Review Press, 1967, New York.

3. Among the most prominent studies, we can quote B. Balassa "Exports and Economic Growth: Further Evidence", Journal of Development Economics, 1978, 5, pp. 181-189., and H. W. Singer, and P. Gray "Trade Policy and Growth of Developing Countries: Some New Data", World Development, 1987, 16 (3), pp. 395-403., for the level of economic development; R. Ram, "Exports and Economic Growth in Developing Countries: Evidence from Time-Series and Cross-Section Data", Economic Development and Cultural Change, 1987, 36, pp. 51-72, D. Greenaway, and N. Chong-Hyun "Industrialisation and Macroeconomic Performance in Developing Countries under Altemative Trade Strategies", Kyklos, 1988, 41 (3), pp. 419-435., for trade orientation; and R. M. Kavoussi, "Export Expansion and Economic Growth: Further Emprical Evidence", Journal of Development Economics, 1984, 14, pp. 241-250., for the commodity composition of trade.

4. This is known as the pioneering study dealing with the relationship between export growth and economic growth in a causality framework.

5. See, Jung and Marshall, p. 10.

6. Ahmad, J. and A. C. C. Kwan, p. 247.

7. New series show substantial differences from the oid ones. 
8. F is calculated as $F=(N-k)\left(S S R_{R}-S S R U\right) / q(S S R U)$ where $S_{S R}$ and SSR.U are sums of squared residuals in the restricted and unrestricted regressions, respectively, while $\mathbf{N}$ is the number of observations, $k$ is the number of estimated parameters in the unrestricted regression, and $q$ is the number of parameter restrictions. This ratio is not distributed as a standart $F$ distribution under the null hypothesis. Instead, the distribution tabulated by Dickey and Fuller must be seen. See, K. S. Pindyck, and D. L. Rubinfeld, Econometric Models and Economic Forecasts, 3rd Edition, McGraw Hill, 1991.

9. It has zero mean and constant variance, and is uncorrelated with any other term in the sequence. That is, $E\left(u_{t}\right)=0, E\left(u_{t}{ }^{2}\right)=\sigma u^{2}$ and $E\left(u_{t} u_{t-k}\right)=0$, for $k \neq 0$.

10. See, Jung and Marshall, p. 4.

11. See, Bahmani-Oskooee, et al., p. 411-412.

12. See, Dodaro, p. 240.

\section{REFERENCES}

Ahmad, J. and A. C. C. Kwan (1991) "Causality between Exports and Economic Growth: Emprical Evidence from Africa", Economics Letters, 37, pp. 243248.

Bahmani-Oskooee, M., H. Mohtadi and G. Shabsigh (1991) "Export, Growth and Causality in LDCs: A Re-examination", Journal of Development Economics, 36, pp. 404-415.

Balassa, B. (1978) "Exports and Economic Growth: Further Evidence", Journal of Development Economics, 5, pp. 181-189.

(1985) "Exports, Policy Choices, and Economic Growth in Developing Countries after the 1973 Oil Shock", Journal of Development Economics, 18, pp. 23-35.

Chow, P. C. Y. (1987) "Causality between Export Growth and Industrial Development: Emprical Evidence from NICs", Journal of Development Economics, 26, pp. 55-63.

Dickey, D. A. and W. A. Fuller (1979) "Distribution of the Estimators for Autoregressive Time Series with a Unit Root", Journal of American Statistical Association, 74, pp. 427-431.

Dodaro, S. (1993) "Exports and Growth: A Re-examination of Causality", Joumal of Developing Areas, 27, pp. 227-244. 
Donges, J. B. and J. Riedel (1977) "The Expansion of Manufactured Exports in Developing Countries: An Emprical Assessment of Supply and Demand Issues", Weltwirtschaftliches Archiv, 113(1), pp. 58-85.

Emery, R. (1967) "The Relation of Exports and Economic Growth", Kyklos, 20, pp. $470-486$.

Engle, R. F. and C. W. J. Granger (1987) "Cointegration and Error Correction: Representation, Estimation and Testing", Econometrica, 55, pp. $251-76$.

Fajana, O. (1979) "Trade and Growth: The Nigerian Experience", World Development, 7. pp. 73-79.

Feder, G. (1982) "On Exports and Economic Growth", Journal of Development Economics, 12, pp. 59-73.

Frank, A. G. (1967) Capitalism and Underdevelopment in Latin America, Monthly Review Press, New York.

Ghartey, E. E. (1993) "Causal Relationship between Exports and Economic Growth: Some Emprical Evidence in Taiwan, Japan and the USA", Applied Economics, 25, pp. 1145-1152.

Goldstein, M. and M. Khan (1982) Effects of Slowdown in Industrial Countries on Growth in Non-Oil Developing Countries, Washington, DC.: IMF Occasional Paper, No: 12.

Gordon, D. V. and K. Sakyi-Bekoe (1993) "Testing the Export-Growth Hypothesis: Some Parametric and Non-parametric Results for Ghana", Applied Economics. 25, pp. 553-563.

Granger, C. (1969) "Investigating Causal Relations by Econometric Models and CrossSpectral Methods, Econometrica, 37(3), pp. 424-438.

Greenaway, D. and N. Chong-Hyun (1988) "Industrialisation and Macroeconomic Performance in Developing Countries under Altemative Trade Strategies", Kyklos, 41 (3), pp. 419-435.

Greene, W. H. (1993) Econometric Analysis, 2nd Edition, Macmillan Publishing Company, New York.

Hsiao, C. (1987) "Causality between Export Growth and Industrial Development: Empirical Evidence from the NICs", Journal of Development Economics, 26, pp, 55-63.

Jung, W. S. and P. J. Marshall (1985) "Exports Growth and Causality in Developing Countries", Journal of Development Economics, 18, pp. 1-12.

Kavoussi, R. M. (1984) "Export Expansion and Economic Growth: Further Emprical Evidence", Journal of Development Economics, 14, pp. 241-250. 
Krueger, A. O. (1980) "Trade Policy as an Input to Development", American Economic Review, 70(2), pp. 288-292.

Maizels, A. (1968) Exports and Economic Growth in Developing Countries, Cambridge University Press, London.

Massell, B. F., S. R. Pearson and J. B. Fitch (1972) "Foreign Exhange and Economic Development: An Emprical Study of Selected Latin American Countries", Review of Economics and Statistics, 54, pp. 208-212.

Michaely, M. (1977) "Exports and Growth: An Emprical Investigation", Journal of Development Economics, 4, pp. 49-53.

Michaloupoulos, C. and J. Keith (1973) "Growth of Exports and Income in Developing World: A Neo-classical View", A.I.D. Discussion Papers, No. 28.

Otani, I and D. Villanueva (1990) "Long Term Growth in Developing Countries and Its Determinants: An Emprical Analysis", World Development, 18 (6), pp. 769. 783.

Oxley, L. (1993) "Cointegration, Causality and Export-Led Growth in Portugal 18651895", Economics Letters, 43, pp. 163-166.

Parikh, A. and D. Bailey (1990) Techniques of Economic Analysis with Applications, Harvester Wheatsheaf, Cambridge.

Pindyck, K. S. and D. L. Rubinfeld (1991) Econometric Models and Economic Forecasts, 3rd Edition, McGraw Hill, International Editions, Economics Series, New York.

Ram, R. (1985) "Exports and Economic Growth: Some Additional Evidence", Economic Development and Cultural Change, 33, pp. 415-425.

(1987) "Exports and Economic Growth in Developing Countries: Evidence from Time-Series and Cross-Section Data, Economic Development and Cultural Change, 36, 51-72.

Riedel, J. (1987) Myths and Reality of External Constraints on Development, Gower, London.

Salvatore, D. (1983) "A Simultaneous Equations Model of Trade and Development with Dynamic Policy Simulations", Kyklos, 36(1), ph. 66-90.

Sengupta, J. K. and J. K. Espana (1994) "Exports and Economic Growth in Asian NICs: An Econometric Analysis for Korea", Applied Economics, 26, pp. 41-51.

Sheehey, E. J. (1990) "Exports and Growth: A Flawed Framework", Journal of Development Studies, 27(1), pp. 110-116. 
(1992) "Exports and Growth: Additional Evidence", Journal of Development Studies, 28(4), pp. 730-734.

Sims, C. A. (1972) "Money, Income and Causality", American Economic Reviev, LXII. 4, pp. 540-552.

Singer, H. W. and P. Gray (1987) "Trade Policy and Growth of Developing Countries: Some New Data", World Development, 16(3), pp. 395-403.

Syron, R.F. and B. M. Walsh (1968) "The Relation of Exports and Economic Growth: A Note", Kyklos, 21(3), pp. 541-545.

Tyler, W. G. (1981) "Growth and Export Expansion in Developing Countries: Some Emprical Evidence", Journal of Development Economics, 9, pp. 121-130.

Voivodas, C. (1973) "Exports, Foreign Capital Inflow and Economic Growth", Joumal of International Economics, 3, pp. 337-349. (1974) "Exports, Foreign Capital Inflow and South Korean Growth", Economic Development and Cultural Change, 22, pp. 480-484.

Williamson, R. B. (1978) "The Role of Exports and Foreign Capital in Latin American Economic Growth". Southem Economic Journal, 45, pp. 410-420. 